\title{
Effect of different milling methods on glycaemic response of foods made with finger millet (Eucenea coracana) flour
}

\author{
M A Jayasinghe ${ }^{1}$, S Ekanayake², D B Nugegoda ${ }^{3}$ \\ (Index words: finger millet flour, processing, particle size, gelatinisation)
}

\begin{abstract}
Objectives Compare glycaemic response of foods prepared with finger millet flour, using traditional stone grinding and industrial milling.

Design Crossover study.

Participants Healthy volunteers $(n=11)$ consisting of five males and six females), aged between 20 and 30 years, with a body mass index of $18.5-23.5 \mathrm{Kgm}^{-2}$.

Main outcome measures Blood glucose concentration was measured at fasting and $30,45,60,90,120$ minutes after ingestion of roti and pittu made with stone ground or industrially milled finger millet flour, containing $50 \mathrm{~g}$ of available carbohydrates. Glycaemic Index (GI) values were expressed as the average value of the 11 subjects.

Results Significant differences $(p<0.05)$ in $\mathrm{Gl}$ between similar food types made of flour milled using different methods were observed. GI for roti made of stone ground flour was $44 \pm 5$ and that of roti made of industrially milled flour was $59 \pm 7$. Pittu made of stone ground flour had a $\mathrm{GI}$ of $67 \pm 5$ and $\mathrm{Gl}$ of pittu made of industrially milled flour was $79 \pm 5$. Microscopic analysis of flour samples and a sieving process using different sieve sizes showed larger particle size distribution in stone ground flour compared to industrially milled flour.

Conclusions Larger particle sizes in the stone ground flour compared with industrially milled flour was established as the only factor affecting the difference in GI of same type of food prepared with flour milled using different methods. There were no significant differences $(p>0.05)$ in proximate compositions of the different foods or raw flours. Foods prepared with finger millet (kurakkan) flour with a larger particle size distribution resulted in a lower glycaemic response.
\end{abstract}

Ceylon Medical Journal 2013; 58: 148-52

\section{Introduction}

Finger millet (Eucenea coracana), known as 'kurakkan' in Sri Lanka, is a cereal crop consumed by millions of people living in South Asia and Africa. The annual world production of finger millet is 4.5 million tons of which Africa produces 2 million tons [1]. The grains are ground and used for baking flatbread, porridges or brewing beer. "Roti", "pittu” and "thalapa" prepared from the flour is popular among the Sri Lankan rural community [2]. There is recent interest in "kurakkan" due to the high fibre content which may for lower blood glucose and cholesterol and also aid the normal peristaltic movement of the bowel $[3,4]$. Hence, finger millet is advocated for individuals suffering from diabetes mellitus (DM) and hypercholesterolaemia.

The prevalence of these diseases are increasing in Sri Lanka, $16.4 \%$ of the urban and $8.7 \%$ of the rural population have diabetes [5]. Therefore dietary change and changes in food production techniques are needed to reduce the incidences of these diseases. Many studies have proven that foods with low or medium glycaemic index (GI) are beneficial in individuals with DM or other non communicable diseases [6].

The GI of food, which reflects postprandial blood glucose elevations after a diet, is be influenced by the particle size of the flour used in food preparation [7]. The particle size depends on the type of milling and particle size of food influences the blood glucose level after consumption. Although finger millet is considered as a suitable food for individuals with diabetes and other non communicable diseases, foods made from commercially available finger millet flour have not shown low GI values as expected [8].

This research was intended to investigate the affect of milling method on the glycaemic index of the foods made of finger millet. Finger millet flour was obtained by grinding with a stone grinder, an instrument traditionally used in preparing flour by the Sri Lankan rural community and flour produced by an industrial mill. The flour thus obtained was used to prepare food, each with the same composition, to investigate the effect on glycaemic responses and GI values and to ascertain if this is due to the difference in milling method.

Departments of ${ }^{1}$ Food Science and Technology and ${ }^{2}$ Biochemistry, Faculty of Applied Sciences, University of Sri Jayewardenepura and ${ }^{3}$ Department of Community Medicine, Faculty of Medicine, Rajarata University, Sri Lanka.

Correspondence: SE, e-mail: <sagarikae@hotmail.com>. Received 6 January 2013 and revised version accepted 23 April 2013. Competing interests: none declared. 


\section{Methods}

A bulk finger millet sample $(20 \mathrm{~kg})$ was obtained from selected farms in Anuradhapura, Sri Lanka. Half of the sample was milled using a rubber roller mill followed by grinding using a pin mill (Hitachi, $1500 \mathrm{rpm}$ ). The other half of the sample was ground using a domestic stone grinder. The test foods (pittu and roti) were prepared according to commonly used household preparation methods in Sri Lanka. The ratio of ingredients for each food were selected after a palatability test which was decided by a panel (non-trained). Two separate groups of food were prepared using flour obtained by different milling methods. Each group of food had the same content of ingredients.

Proximate composition of the raw flour and food were determined. Food flour was obtained by drying cooked food $\left(40^{\circ} \mathrm{C}\right.$, REMITM Laboratory oven, $24 \mathrm{~h}$; REMI Instruments Ltd; Mumbai, India) followed by milling under controlled conditions (IKA ${ }^{\circledR}$ A11 basic, Brazil). The moisture and ash contents were measured by AOAC official methods $[9,10]$. The digestible carbohydrate content, fat and soluble and insoluble dietary fibre were determined with Holm's method, Croon and Guchs and by the method of Asp respectively [11-13]. The crude protein was determined by Kjeldahl method using Mercury catalyst [14].

Equal weights of differently milled raw flour were sieved using $0.05 \mathrm{~mm}$ and $0.1 \mathrm{~mm}$ sieves and weights of sieved and retained flour fractions on each sieve were measured (Citizen, model CY 220). Flour samples with different particle sizes were stained with iodine solution $\left(\mathrm{KI} / \mathrm{I}_{2}\right)$ and observed under the microscope $(10 \times 5$ magnification, OLYMPUS, UK). Photographs of the fields were taken. A commercially available flour sample and a flour sample prepared by milling Eucenea grains from the same bulk sample using a household mill were also sieved and compound with the above.

Approval for study was obtained from the Ethical Review Committee, Faculty of Medical Sciences, University of Sri Jayewardenepura, Sri Lanka. Informed written consent was obtained from all participants prior to the study.

Determination of the GI was carried out as a crossover study, as described by Brouns et al. in 2005 [15]. Healthy volunteers $(n=11)$ including both sexes $(5$ males and 6 females), aged 20 - 30 years, with a body mass index of 18.5-23.5 $\mathrm{Kgm}^{-2}$ were selected. The subjects were asked to refrain from smoking, drinking alcohol and to restrict vigorous physical activity the day before.

Following an overnight fast of 10 hours, a finger prick capillary blood sample was obtained from the subject. Glucose was used as the standard food $(\mathrm{GI}=100)$. The test food (within 2 hours of preparation) and the standard food were served to the same individual on separate occasions. The subject was served with standard or test food containing $50 \mathrm{~g}$ (roti or pittu) of digestible carbohydrate portions to be consumed within 10-15 minutes with $250 \mathrm{ml}$ drinking water. Capillary blood samples were collected at $30,45,60,90$ and $120 \mathrm{~min}$ after the first bite of the meal. Serum glucose concentrations were determined with a Glucose-Oxidase kit (BIOLABOSATM; Biolabosa, France). The GI was calculated using the mean of the individual incremental area under the curve of the test food and of the standard food [15]. The glycaemic load (GL) values of foods were calculated. (GL $=\mathrm{GI} *$ digestible starch per serving $(\mathrm{g})) / 100)$.

Proximate composition values are expressed as the mean \pm standard deviation. GI values of foods are expressed as the mean with SEM. The means of the GI values of foods were compared using a paired Student's t-test. Microsoft Excel 2007 was used for statistical analysis.

\section{Results}

The proximate composition of the two flour samples and food made of these flour samples are given in Table 1 . A significant difference was not observed $(p>0.05)$ in the macronutrient contents between roti and pittu made using either stone ground or industrially milled flour. Compared to the differently milled flour samples, fat content in both foods increased significantly $(p<0.05)$ due to the addition of coconut kernel (Table 1). There was no significant difference in proximate composition of the edible portion $(50 \mathrm{~g})$ in the same type of foods prepared with either type of flour (Table 1).

Roti made of industrially milled flour (Roti 1) and of stone ground flour (Roti 2) had GI values of $59 \pm 7$ (medium GI) and $44 \pm 5$ (low GI) respectively. Pittu made of industrially milled flour (Pittu 1) and stone ground flour (Pittu 2) had GI values of $79 \pm 5$ (high GI) and $67 \pm 4$ (medium GI) respectively (Table 2 ).

A shift from medium to low GI in roti and from high GI to medium GI in pittu was observed, when the flour was changed from industrially milled to stone ground. These differences were significant $(p<0.05)$. The glycaemic response curves (Figures 1 and 2) clearly indicate a lower and a delayed peak in both pittu and roti made with stone ground flour. Peak reductions of $9.3 \mathrm{mg} / \mathrm{dL}$ and $7.9 \mathrm{mg} / \mathrm{dL}$ were seen for roti and pittu respectively and peaking times were delayed by 15 minutes (Table 2).

Peak glucose concentrations of pittu were relatively higher than those of roti, even though the flour samples used to prepare them were milled using same methods (Figure 1). According to the Glycaemic Load scale, GL values $\geq 20$ are considered as high, between 11 to 19 as intermediate and GL $\leq 10$ as low. Hence, all the test foods had high GL values (Table 2). 
The evidence obtained after the sieving process (Table 3) showed that a high percentage of the particles were smaller than $0.05 \mathrm{~mm}$ in the industrially ground flour (45.6\%), but this percentage is lower in the stone ground flour (34.8\%). A similar pattern was observed for other sieve sizes as well (Table 3). A commercially available sample had a similar particle size distribution to the flour obtained using an industrial mill. However, if the grains can be ground at household level, the particle size can be controlled. This was demonstrated by grinding a sample of kurakkan using a household grinder (IKA ${ }^{\circledR}$ A11 basic, Brazil) under controlled conditions, where we obtained a particle size distribution similar to that of stone ground flour (Table 3).

Table 1. Proximate composition of flour, roti and pittu on dry weight basis

\begin{tabular}{|c|c|c|c|c|c|c|c|c|}
\hline Flour variety & $\begin{array}{l}\text { Protein } \\
\%(d w)\end{array}$ & $\begin{array}{c}\text { Total fibre } \\
\%(d w)\end{array}$ & $\begin{array}{c}\text { Soluble } \\
\text { dietary } \\
\text { fibre \% } \\
(d w)\end{array}$ & $\begin{array}{c}\text { Insoluble } \\
\text { dietary } \\
\text { fibre } \\
\%(d w)\end{array}$ & Fat $\%(d w)$ & $\begin{array}{c}\text { Mineral } \\
\text { ash \% } \\
(d w)\end{array}$ & $\begin{array}{c}\text { Available } \\
\text { carbohydrates } \\
\%(d w)\end{array}$ & $\begin{array}{c}\% \text { Moisture } \\
(w b)\end{array}$ \\
\hline $\begin{array}{l}\text { Rubber roller } \\
\text { milled finger } \\
\text { millet flour } \\
\text { (Flour 1) }\end{array}$ & $3.1 \pm 0.5$ & 23.0 & $8.2 \pm 0.8$ & $14.8 \pm 0.9$ & $1.9 \pm 0.2$ & $1.6 \pm 0.3$ & $68.5 \pm 4$ & $12.8 \pm 0.2$ \\
\hline $\begin{array}{l}\text { Stone ground } \\
\text { finger millet } \\
\text { flour (Flour 2) }\end{array}$ & $3.9 \pm 0.7$ & 23.8 & $8.7 \pm 0.6$ & $15.1 \pm 0.8$ & $2.0 \pm 0.4$ & $1.9 \pm 0.4$ & $65.6 \pm 4$ & $9.5 \pm 0.1$ \\
\hline $\begin{array}{l}\text { Roti made of } \\
\text { rubber roller } \\
\text { milled finger } \\
\text { millet flour } \\
\text { (Roti 1) }\end{array}$ & $3.9 \pm 0.7$ & 21.3 & $6.9 \pm 0.5$ & $14.4 \pm 0.4$ & $14.5 \pm 0.4$ & $2.4 \pm 0.3$ & $54.4 \pm 4$ & $8.3 \pm 0.2$ \\
\hline $\begin{array}{l}\text { Roti made of } \\
\text { stone ground } \\
\text { finger millet } \\
\text { flour (Roti 2) }\end{array}$ & $4.2 \pm 0.6$ & 22.4 & $7.5 \pm 0.4$ & $14.9 \pm 0.6$ & $15.0 \pm 0.7$ & $2.6 \pm 0.2$ & $53.8 \pm 5$ & $8.1 \pm 0.3$ \\
\hline $\begin{array}{l}\text { Pittu made of } \\
\text { rubber roller } \\
\text { milled flour } \\
(\text { Pittu 1) }\end{array}$ & $4.9 \pm 0.6$ & 20.4 & $6.2 \pm 0.4$ & $14.2 \pm 0.5$ & $15.9 \pm 0.5$ & $2.5 \pm 0.2$ & $52.4 \pm 4$ & $22.1 \pm 0.7$ \\
\hline $\begin{array}{l}\text { Pittu made of } \\
\text { stone ground } \\
\text { flour (Pittu 2) }\end{array}$ & $4.4 \pm 0.5$ & 21.6 & $6.9 \pm 0.4$ & $14.7 \pm 0.7$ & $14.6 \pm 0.4$ & $1.9 \pm 0.4$ & $53.1 \pm 6$ & $22.3 \pm 0.6$ \\
\hline Scraped coconut & $8.0 \pm 0.7$ & 24.4 & $8.3 \pm 0.5$ & $16.1 \pm 0.8$ & $36.1 \pm 1.1$ & $2.6 \pm 0.3$ & $16.5 \pm 0.4$ & $38.0 \pm 1.2$ \\
\hline
\end{tabular}

Table 2. Glycaemic indices of roti and pittu

\begin{tabular}{|c|c|c|c|}
\hline $\begin{array}{l}\text { Roti made of } \\
\text { industrially milled } \\
\text { finger millet flour } \\
\text { (Roti 1) }\end{array}$ & $\begin{array}{l}\text { Roti made of } \\
\text { Stone ground } \\
\text { finger millet } \\
\text { flour (Roti 2) }\end{array}$ & $\begin{array}{l}\text { Pittu made of } \\
\text { industrially } \\
\text { millet flour } \\
\text { (Pittu 1) }\end{array}$ & $\begin{array}{l}\text { Pittu made of } \\
\text { stone ground } \\
\text { flour (Pittu 2) }\end{array}$ \\
\hline
\end{tabular}

\begin{tabular}{|c|c|c|c|c|}
\hline Mean GI & $59 \pm 7$ & $44 \pm 5$ & $79 \pm 5$ & $67 \pm 4$ \\
\hline Standard error mean & 6.7 & 5.2 & 4.6 & 4.4 \\
\hline Portion size & $101.4 \mathrm{~g}$ & $102.1 \mathrm{~g}$ & $164.4 \mathrm{~g}$ & $162.7 \mathrm{~g}$ \\
\hline Peaking time & $30 \mathrm{~min}$. & $45 \mathrm{~min}$. & $30 \mathrm{~min}$. & $45 \mathrm{~min}$. \\
\hline Peak reduction & - & $9.3 \mathrm{mg} / \mathrm{L}$ & - & $7.9 \mathrm{mg} / \mathrm{L}$ \\
\hline$\%$ GI reduction & - & $26.4 \%$ & - & $15.2 \%$ \\
\hline Glycaemic load & 30 & 22 & 40 & 34 \\
\hline
\end{tabular}


Table 3. Particle size distribution following sieving finger millet flour

\begin{tabular}{|c|c|c|c|c|c|c|c|}
\hline Sieve size & $\begin{array}{c}\text { Sample weight } \\
\text { (g) }\end{array}$ & $\begin{array}{l}\text { Unsieved weight } \\
\text { (g) }\end{array}$ & $\%$ & $\begin{array}{l}\text { Sieved weight } \\
\text { by } 0.1 \mathrm{~mm} \\
\text { sieve }(\mathrm{g})\end{array}$ & $\%$ & $\begin{array}{c}\text { Sieved weight } \\
\text { by } 0.05 \mathrm{~mm} \\
\text { sieve }(\mathrm{g})\end{array}$ & $\%$ \\
\hline $\begin{array}{l}\text { Flour ground by } \\
\text { industrial mills }\end{array}$ & 25.0 & 5.8 & 23.2 & 7.8 & 31.2 & 11.4 & 45.6 \\
\hline $\begin{array}{l}\text { Commercially } \\
\text { available flour } \\
\text { (Ruhunu brand) }\end{array}$ & 25.0 & 5.8 & 23.2 & 8.0 & 32.0 & 11.2 & 44.8 \\
\hline Stone ground flour & 25.0 & 7.6 & 30.4 & 8.7 & 34.8 & 8.7 & 34.8 \\
\hline $\begin{array}{l}\text { Flour ground using } \\
\text { the Analytical mill } \\
\text { (IKA }{ }^{\circledR} \text { A11 basic, } \\
\text { Brazil) }\end{array}$ & 25.0 & 7.1 & 28.4 & 9.0 & 36.0 & 8.9 & 35.6 \\
\hline
\end{tabular}

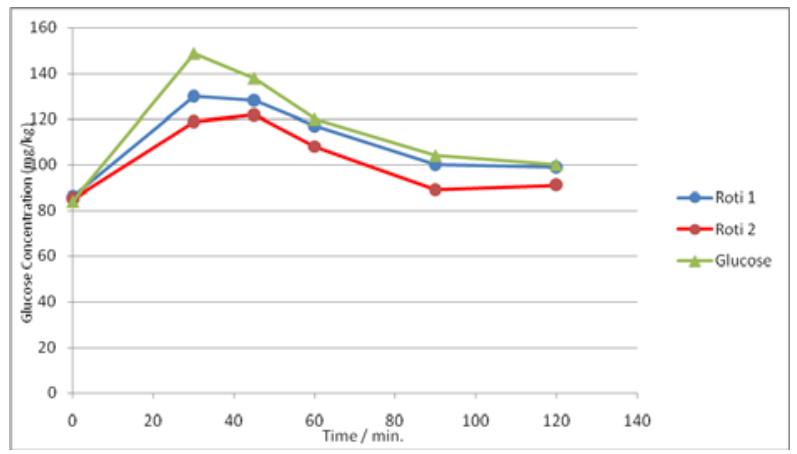

Roti 1: Made of industrially milled flour Roti 2: Made of stone ground flour

Figure 1. Blood glucose response curves for Roti.

The above was further proven when microscopic photographs of stained flour samples indicated that the average particle size of the stone ground finger millet flour was much higher than that of the flour milled using industrial machines (Figure 3 and 4 ).

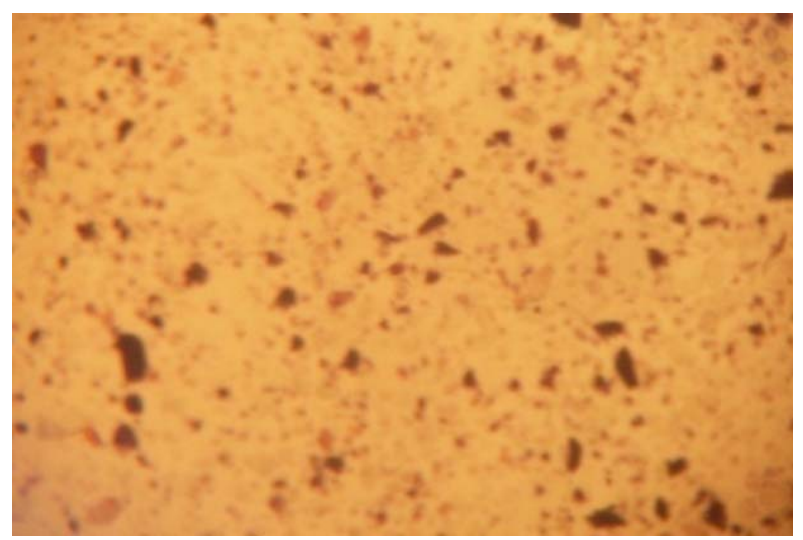

Figure 3. Microscopic fields $(10 \times 5)$ of industrially milled flour stained using iodine.

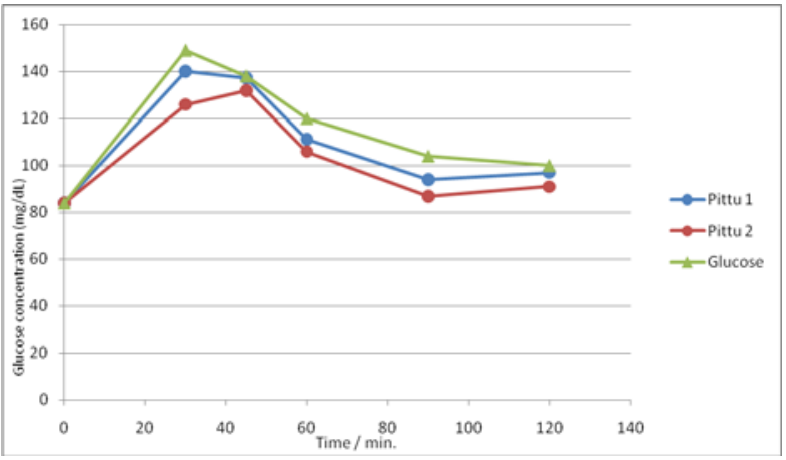

Pittu 1: Made of industrially milled flour Pittu 2: Made of stone ground flour

Figure 2. Blood glucose response curves for Pittu.

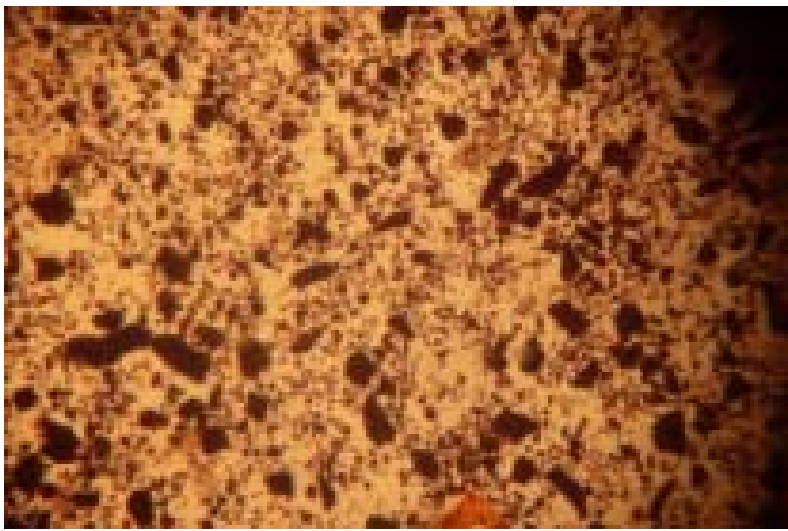

Figure 4. Microscopic fields $(10 \times 5)$ of stone ground flour stained.

The above was further proven when microscopic photographs of stained flour samples indicated that the average particle size of the stone ground finger millet flour was much higher than that of the flour milled using industrial machines (Figure 3 and 4). 


\section{Discussion}

Since no significant difference was observed in macronutrient content between the pittu or roti made with flour milled using different methods, the particle size was considered the crucial factor causing the significant difference observed in GI values of the same food type.

A previous study reported high GI for kurakkan flour and wheat flour pittu (GI 64 and 75 respectively) [8]. Both foods elicited higher peak glucose concentrations compared to roti. This indicates that the method of cooking should be considered an important factor. The increased gelatinisation of starch granules caused the high blood glucose response for pittu compared to that of roti, proving that processing method which affects the gelatinisation of starch is one of the most important factors in determination of GI [8]. Glycaemic load allows comparisons of the glycaemic effect of realistic portions of different foods. It is calculated by multiplying the amount of carbohydrate in one serving by the GI of the food.

The majority of volunteers mentioned that the portion size of roti was sufficient but portion size of pittu was large. Although the GL values obtained for roti are quite acceptable, the GL values for pittu may be lower, when considering the actual portion size of a daily consumed meal. The large particle size of flour makes the starch gelatinisation relatively difficult and thus slows the enzyme attack, resulting in slow release of glucose from food, which prevents high peaks in postprandial blood glucose levels [16]. This causes a significant decrease in the glycaemic response, the peaking and glycaemic indices of pittu and roti made using stone ground flour.

It has been suggested that the lower postprandial blood glucose levels may decrease the risk of hyperglycaemia and weight gain. On the other hand, sustained higher levels of blood sugar levels cause damage to blood vessels and to the organs they supply, leading to complications of diabetes. Thus, consumption of foods associated with lower peaks in blood glucose concentration is extremely important in controlling complications arising due to diabetes and in preventing development of other chronic non-communicable diseases [7].

In conclusion industrially milled flour with relatively smaller particle size distribution elicited higher GIs compared to food made of stone ground flour, where the particle size was larger. Since no significant difference was observed in proximate compositions of similar foods made of differently milled flour, particle size has to be the major factor contributing to the significant differences observed in GIs of those foods.

\section{References}

1. Vietmeyer ND, Colombani K. eds. Lost Crops of Africa. 1996. Abuja: Grandwil, 1997.

2. Chandrasekara SR. Traditional Sri Lankan diet. Diabetes Care 2002; 25: 14-6.

3. Brand JC, Colagiuri S, Foster K. The glycaemic index is easy and works in practice. Diabetes Care 1997; 20: 1628-9.

4. Brand JC, Colagiuri S, Crossman S, et al. Low-glycaemic index foods improve long-term glycaemic control in NIDDN. Diabetes Care 1991; 14: 95-101.

5. Katulanda P, Constantine GR, Mahesh JG, et al. Prevalence and projections of diabetes and pre-diabetes in adults in Sri Lanka Diabetes, cardiovascular study (SCDCS). Diabetic Medicine 2008; 25: 1062-9.

6. Potter JG, Coffman KP, Reid RL, Krall JM, Albrink MJ. Effect of test meals of varying dietary fiber content on plasma insulin and glucose response. American Journal of Clinical Nutrition 1981; 34: 328-34.

7. Thomas DE, Elliot EJ, Baur L. Low glycaemic index or low glycaemic load diets for overweight and obesity. Cochrane Database of Systematic Reviews 2007; 18: CD005105.

8. Widanagamage R, Ekanayake S, Welihinda J. Carbohydrate rich foods: glycaemic indices and the effect of constituent macronutrients. International Journal of Food Sciences and Nutrition 2009; 60: 215-23.

9. Association of Official Analytical Chemists. Official Methods of Analysis of the AOAC 1984; AOAC: Washington DC, 7.009 .

10. Association of Official Analytical Chemists. Official Methods of Analysis of the AOAC 1984; AOAC: Washington DC, 14.004 .

11. Holm J, Bjorck I, Drews A, Asp NG. A rapid method for the analysis of starch. Starch/Starke 1986; 38: 224-6.

12. Croon LB. Crude fat analysis of different flours and flour products. Var Foda 1980; 32: 425-7.

13. Asp NG, Johansson CG, Hallmer H, Siljestrom M. Rapid enzymatic assay of insoluble and soluble dietary fiber. Journal of Agriculture and Food Chemistry 1983; 31: 476-8.

14. Association of Official Analytical Chemists. Official Methods of Analysis of the AOAC; AOAC 1987: Washington DC, 7.033.

15. Brouns F, Bjorck I, Frayn KN, et al. Glycaemic index methodology. Nutrition Research Reviews 2005; 18: 145-71.

16. Nuttall F, Mooradian AD, Gannon MC, et al. Effect of protein ingestion on the glucose and insulin response to a standardized oral glucose load. Diabetes Care 1984; 7: 465-70. 